\title{
E-Learning Efektif Sebagai Media Pembelajaran Saat Pandemi Covid-19
}

\section{Elda Permata Sari ${ }^{*}$, Muldi Yuhendri²}

1,2 Universitas Negeri Padang, Padang, Indonesia

\section{ART ICLE IN F O}

Article history:

Received September 19, 2021

Revised September 20, 2021

Accepted November 27, 2021

Available online December 25, 2021

Kata Kunci:

E-Learning, Media Pembelajaran, TCR

Keywords:

E-learning, Learning Media, TCR

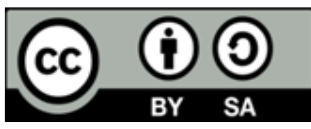

This is an open access article under the CC BY-SA license.

Copyright $(2021$ by Author. Published by Universitas Pendidikan Ganesha.

\begin{abstract}
A B S T R A K
Masih banyak mahasiswa yang belum familiar akan fitur Big Blue Button ini dikarenakan belum optimalnya sosialisasi terhadap fitur yang ada di E-learning. Selain itu, banyak dosen yang lebih memilih menggunakan zoom cloud meetings karena pemakaiannya lebih mudah dan stabil. Penelitian ini bertujuan untuk menganalisis efektivitas penggunaan E-learning sebagai media pembelajaran saat pandemi covid-19. Penelitian ini adalah penelitian deskriptif dengan metode kuantitatif. Teknik pengumpulan data menggunakan kuesioner yang diberikan melalui google form. Subjek penelitian ini adalah mahasiswa pascasarjana pendidikan teknologi dan kejuruan sejumlah 21 mahasiswa. Teknik sampling yang digunakan dalam penelitian ini adalah probability sampling. Pengambilan sampel menggunakan Simple Random Sampling. Kuesioner dibuat memakai skala likert yang ada lima alternatif jawaban. Teknik yang digunakan untuk menganalisis data yaitu analisis statistic kualitatif dan kuantitatif. Hasil penelitian yaitu indikator tujuan pembelajaran dilihat bahwa tingkat capaian responden (TCR) mencapai $77,20 \%$ dengan kategori cukup. Indikator sarana prasarana pembelajaran dilihat bahwa TCR mencapai $82,07 \%$ dengan kategori baik. Indikator kemampuan menggunakan teknologi dilihat bahwa TCR mencapai $81,18 \%$ dengan kategori baik. Indikator efisiensi waktu dilihat bahwa TCR mencapai $81,93 \%$ dengan kategori baik. Indikator hasil pembelajaran dilihat bahwa TCR mencapai $86,70 \%$. Dengan demikian dapat disimpulkan bahwa penggunaan E-learning sebagai media pembelajaran saat pandemi covid-19 dikategorikan efektif, bisa dilihat dari hasil penelitian pada 5 indikator ada 4 indikator yang kategori baik dan ada 1 yang kategori cukup.
\end{abstract}

\section{A B S T RACT}

There are still many students who are not familiar with the Big Blue Button feature because the socialization of the features in E-learning has not been optimal. In addition, many lecturers prefer to use zoom cloud meetings because it is easier and more stable to use. This study aims to analyze the effectiveness of using E-learning as a learning medium during the covid-19 pandemic. This research is descriptive research with the quantitative method. The data collection technique used a questionnaire given via google form. The subjects of this study were postgraduate students of technology and vocational education with 21 students. The sampling technique used in this study is probability sampling. Sampling using Simple Random Sampling. The questionnaire was made using a Likert scale with five alternative answers. The technique used to analyze the data is qualitative and quantitative statistical analysis. In the study's results, namely indicators of learning objectives, it was seen that the level of achievement of respondents (TCR) reached $77.20 \%$ with a sufficient category. The indicator of learning infrastructure shows that the TCR reaches $82.07 \%$, with a good category. The indicator of the ability to use technology shows that the TCR reaches $81.18 \%$ in the good category. The time efficiency indicator shows that the TCR reaches $81.93 \%$ with a good category. Indicators of learning outcomes seen that the TCR reached $86.70 \%$. E-learning as a learning medium during the COVID-19 pandemic is categorized as effective. It can be seen from the results of research on five indicators, there are four indicators in the good category, and one is in the sufficient category. 


\section{PENDAHULUAN}

Organisasi Kesehatan Dunia di tahun 2020 mengeluarkan pengumuman bahwa Coronavirus Disease 2019 (covid-19) merupakan suatu pandemi yang mewabah ke seluruh dunia (Calvo et al., 2020; Guan et al., 2020; Yulia, 2020). Kondisi seperti ini menjadi krusial pada setiap belahan dunia untuk menerapkan kebijakan agar masyarakat dapat mengurangi aktivitas yang dilaksanakan di luar dan tetap di rumah (Hincal \& Alsaadi, 2021; Tang et al., 2021). Presiden Republik Indonesia mengeluarkan kebijakan dalam menindak lanjuti penyebaran virus ini, dengan menerapkan Physical Distancing. Organisasi Kesehatan Dunia mengatakan bahwa Physical Distancing merupakan suatu perilaku menjaga jarak fisik dalam menghindari penyebaran virus corona (Browning et al., 2021; Shah et al., 2020; Wen et al., 2020). Peristiwa penyebaran virus corona ini berdampak pada sector Pendidikan (Ali, 2020; Maulana \& Iswari, 2020). Hal ini yang menyebabkan pemerintah mengeluarkan Surat Edaran Nomor 4 Tahun 2020 mengenai penyelenggaraan pendidikan selama covid-19. Hal ini disebabkan untuk mencegah penyebaran covid-19 di perguruan tinggi maka pembelajaran mahasiswa dilaksanakan secara daring (dalam jaringan) (Hanik, 2020; Putri, 2020; Tamboto et al., 2021). Universitas Negeri Padang merupakan salah satu lembaga pendidikan yang menggunakan E-learning untuk proses pembelajaran sebagai media pembelajaran. Berdasarkan intruksi dari Kementrian Pendidikan dan Kebudayaan. Universitas Negeri Padang mengeluarkan Surat Edaran Rektor tentang kegiatan kampus dalam merespon tinggi penyebaran covid-19 di Sumatera Barat dalam status Kejadian Luar Biasa (KLB). Semua aktifitas pembelajaran atau perkuliahan dilaksanakan secara daring dengan memanfaatkan berbagai layanan yang disediakan dalam jaringan internet. Sejak pandemi pada tahun ajaran Januari - Juni 2021 Universitas Negeri Padang Pada Program Pasca Sarjana Pendidikan Teknologi dan Kejuruan (PTK) telah melakukan perkuliahan daring. Artinya semua proses pembelajaran dilakukan secara online tidak tatap muka di dalam ruang kelas seperti biasanya.

Penerapan pembelajaran secara daring di UNP menggunakan E-learning dikombinasikan dengan platform online lainnya seperti zoom cloud meetings, whatsApp, dan google meet. Kombinasi platform online lainnya bertujuan untuk mempermudahkan proses pembelajaran dan komunikasi mahasiswa dengan dosen (Abuhassna, Al-rahmi, et al., 2020; Abuhassna, Al-Rahmi, et al., 2020; Bipinchandra et al., 2014). Selain itu UNP menghadirkan fasilitas di E-learning dengan fitur Big Blue Button dengan url https://elearning2.unp.ac.id yang digunakan untuk meeting online atau perkuliahan online. Big Blue Button merupakan sistem dari web conference yang dikembangkan untuk pembelajaran daring (Iswara \& Yasa, 2021; Rangga et al., 2016). Big blue button memungkinkan terjadinya bertukar suara dan gambar, termasuk chat, presentasi dan lainya. Masih banyak mahasiswa yang belum familiar akan fitur Big Blue Button ini dikarenakan belum optimalnya sosialisasi terhadap fitur yang ada di E-learning dan banyak dosen yang lebih memilih menggunakan zoom cloud meetings karena pemakaiannya lebih mudah dan stabil. Hanya beberapa dosen saja yang menggunakan fitur Big Blue Button di E-learning ini. Walaupun kondisi dalam keadaan pandemi covid-19 ini pembelajaran tetap harus berjalan tidak bisa dihentikan, oleh sebab itu digunakan media pembelajaran E-learning. Efektivitas dari penggunaan E-learning sebagai media pembelajaran berkaitan dengan faktor penerimaan seseorang terhadap suatu sistem informasi dan komunikasi yang baru, sehingga mahasiswa mempunyai kesiapan dalam menggunakan E-learning. Efektivitas pembelajaran perlu dikaji untuk melihat keberhasilan sistem yang diterapkan oleh perguruan tinggi pada pembelajaran online.

Dalam mendukung pembelajaran daring, platform E-learning dimanfaatkan sebagai media pembelajaran pengganti tatap muka di kelas (Gerhardt-Szép et al., 2017; Soni et al., 2018; Weldon et al., 2021). Istilah E-learning berasal dari penggunaan internet dan teknologi informasi dan komunikasi. Penggunaan internet memudahkan pelaksanaan pembelajaran jarak jauh yang terintegrasi dengan pembelajaran berbasis online (Khasawneh et al., 2016; Mayer, 2017; Sayıner \& Ergönül, 2021). Electronic Learning yang disingkat menjadi E-learning merupakan suatu pemanfaatan media elektronik yang menggunakan jaringan internet sebagai penemuan baru untuk sistem pembelajaran (Astalini et al., 2019; Pratiwi et al., 2016). Temuan penelitian sebelumnya menyatakan bahwa penggunaan E-learning dapat meningkatkan semangat dan motivasi belajar siswa sehingga efektif untuk digunakan (Aris et al., 2019; Khamparia \& Pandey, 2017). Temuan penelitian lainnya juga menyatakan bahwa penggunaan E-learning sangat memudahkan siswa belajar dimana saja dan kapan saja (Anitha Kumari et al., 2020; Shetu et al., 2021; Velan et al., 2015). Dapat disimpulkan bahwa penggunaan E-learning sangat tepat pada pandemic covid-19 yang mengharuskan seseorang untuk belajar dari rumah. Kehadiran E-learning dapat membantu dosen dengan mahasiswa agar berkomunikasi lebih maksimal Selain media pembelajaran E-learning yang dipersiapkan dalam proses pembelajaran daring, ada faktor lain yang harus diperhatikan seperti motivasi belajar, karena motivasi juga berpengaruh dalam perubahan pembelajaran konvensional menjadi pembelajaran yang menggunakan E-learning. Belum adanya kajian mengenai efektivitas penggunaan $E$ learning sebagai media pembelajaran saat pandemi covid-19 pada semester Januari-Juni 2021 program 
studi Pendidikan Teknologi dan Kejuruan Universitas Negeri Padang. Tujuan penelitian ini yaitu untuk menganalisis efektifitas penggunaan E-learning sebagai media pembelajaran saat pandemi covid-19 pada semester Januari-Juni 2021 program studi Pendidikan Teknologi dan Kejuruan Universitas Negeri Padang.

\section{METODE}

Jenis penelitian ini yaitu deskriptif dengan metode kuantitatif. Dalam penelitian ini untuk metode penelitian yang digunakan merupakan metode kuantitatif karena dengan metode yang digunakan untuk menciptakan sesuatu informasi penelitian berbentuk angka- angka serta analisis memakai statistic. Teknik sampling yang digunakan dalam penelitian ini adalah probability sampling yang berarti memberikan peluang yang sama bagi setiap anggota populasi untuk dipilih menjadi sampel (Sugiyono, 2018). Untuk pengambilan sampelnya menggunakan Simple Random Sampling adalah pengambilan anggota sampel yang dilakukan acak tanpa memperhatikan strata dalam populasi (Sugiyono, 2018). Sampel penelitian ini merupakan Mahasiswa S2 Pendidikan Teknologi dan Kejuruan Universitas Negeri Padang Kelas A Tahun Masuk 2020. Teknik pengumpulan data menggunakan kuesioner yang diberikan melalui google form. Kuesioner dibuat memakai skala likert yang ada lima alternatif jawaban. Skala Likert digunakan untuk mengukur sikap, pendapat dan persepsi individu atau sekelompok orang. Teknik analisis data penelitian untuk melihat pencapaian terhadap indikator yang ada. Data kuantitatif dikumpul melalui kuesioner yang terdiri dari 21 butir pernyataan yang telah diuji validitas dan reliabilitasnya. Teknik yang digunakan untuk menganalisis data yaitu analisis statistic kualitatif dan kuantitatif.

\section{HASIL DAN PEMBAHASAN}

\section{Hasil}

Berdasarkan hasil penelitian yang telah dilakukan terhadap data, seluruh data yang masuk memenuhi syarat untuk diolah dan dianalisis. Secara singkat dapat dinyatakan bahwa deskripsi data ini mengungkapkan informasi tentang jumlah data, mean, median, modus, nilai minimum, nilai maksimum, standar deviasi, dan varians yang diperoleh. Data kuantitatif dikumpul melalui kuesioner yang terdiri dari 21 butir pernyataan yang telah diuji validitas dan reliabilitasnya. Selanjutnya kuesioner diberikan kepada 21 mahasiswa. Berdasarkan hasil analisis data, jumlah data (N) sebanyak 21, mean 85.76, median 85, modus 94, standar deviasi 9.09, variance 82,59, nilai minimum 72, nilai maksimum 105 dan jumlah skor keseluruhan sebesar 1801. Hasil penelitian dengan indikator tujuan pembelajaran yang terdiri dari 2 pertanyaan. Berikut analisis data dari masing-masing pernyataan. Hasil analisis data menunjukan hasil capaian responden pada indikator tujuan pembelajaran berdasarkan data hasil pengolahan kuisioner yang disebarkan kepada 21 mahasiswa S2 PTK FT memiliki persentase sebesar 16,66\% mengatakan sangat baik $54,77 \%$ mengatakan baik, yang mengatakan cukup 26,19\% untuk yang mengatakan kurang baik 2,38\%, dan yang mengatakan sangat kurang baik yang nilainya $0 \%$. Skor ideal maksimal adalah 5 dimana indikator tujuan pembelajaran diperoleh skor rata-rata 3,86 selanjutnya dilakukan analisa data dengan melihat Tingkat Capaian Responden (TCR) menggunakan analisis persen. Indikator tujuan pembelajaran berdasarkan data hasil berada pada kategori "cukup" dengan tingkat capaian responden 77,20\%.

Hasil penelitian dengan indikator sarana prasarana pembelajaran yang terdiri dari 6 pertanyaan. Berdasarkan hasil analisis data, capaian responden pada indikator sarana prasarana pembelajaran berdasarkan data hasil pengolahan kuisioner yang disebarkan kepada 21 mahasiswa S2 PTK FT memiliki persentase sebesar 30,16\% mengatakan sangat baik, 53,17\% mengatakan baik, yang mengatakan cukup $13,50 \%$ untuk yang mengatakan kurang baik $3,17 \%$ dan yang mengatakan sangat kurang baik yang nilainya $0 \%$. Skor ideal maksimal adalah 5 dimana indikator tujuan pembelajaran diperoleh skor rata-rata 4,10 selanjutnya dilakukan analisa data dengan melihat Tingkat Capaian Responden (TCR). Indikator sarana prasarana pembelajaran berdasarkan data hasil berada pada kategori "baik" dengan tingkat capaian responden $83,04 \%$. Hasil penelitian dengan indikator kemampuan menggunakan teknologi yang terdiri dari 8 pertanyaan. Berdasarkan hasil analisis data, didapatkan bahwa capaian responden pada indikator kemampuan menggunakan teknologi berdasarkan data hasil pengolahan kuisioner yang disebarkan kepada 21 mahasiswa S2 PTK FT memiliki persentase sebesar 25\% mengatakan sangat baik, $57,14 \%$ mengatakan baik, yang mengatakan cukup 16,67\% untuk yang mengatakan kurang baik 1,19\% dan yang mengatakan sangat kurang baik yang nilainya $0 \%$. Skor ideal maksimal adalah 5 dimana indikator tujuan pembelajaran diperoleh skor rata-rata 4,06 selanjutnya dilakukan analisa data dengan melihat Tingkat Capaian Responden (TCR). Indikator kemampuan menggunakan teknologi berdasarkan data hasil berada pada kategori "baik" dengan tingkat capaian responden 81,18\%.

Hasil penelitian dengan indikator efisiensi waktu yang terdiri dari 3 pertanyaan. Berdasarkan hasil analisis data, hasil capaian responden pada indikator efisiensi waktu berdasarkan data hasil 
pengolahan kuisioner yang disebarkan kepada 21 mahasiswa S2 PTK FT memiliki persentase sebesar 30,16\% mengatakan sangat baik, 52,38\% mengatakan baik, yang mengatakan cukup 14,29\% untuk yang mengatakan kurang baik $3,17 \%$ dan yang mengatakan sangat kurang baik yang nilainya $0 \%$. Skor ideal maksimal adalah 5 dimana indikator tujuan pembelajaran diperoleh skor rata-rata 4,10 selanjutnya dilakukan analisa data dengan melihat Tingkat Capaian Responden (TCR) menggunakan analisis persen. Indikator efisiensi waktu berdasarkan data hasil berada pada kategori "baik" dengan tingkat capaian responden $81,93 \%$.

Hasil penelitian dengan indikator hasil pembelajaran yang terdiri dari 2 pertanyaan. Berdasarkan hasil analisis data, hasil capaian responden pada indikator hasil pembelajaran berdasarkan data hasil pengolahan kuisioner yang disebarkan kepada 21 mahasiswa S2 PTK FT memiliki persentase sebesar $33,33 \%$ mengatakan sangat baik, 66,67\% mengatakan baik, yang mengatakan cukup 0\% untuk yang mengatakan kurang baik $0 \%$ dan yang mengatakan sangat kurang baik yang nilainya 0\%. Skor ideal maksimal adalah 5 dimana indikator tujuan pembelajaran diperoleh skor rata-rata 4,34 selanjutnya dilakukan analisa data dengan melihat Tingkat Capaian Responden (TCR) menggunakan analisis persen. Indikator hasil pembelajaran berdasarkan data hasil berada pada kategori "baik" dengan tingkat capaian responden 86,70\%. Secara keseluruhan hasil dari efektivitas penggunaan E-learning sebagai media pembelajaran saat pandemi covid-19 program studi pendidikan teknologi dan kejuruan Universitas Negeri Padang digambarkan kedalam diagram pada Gambar 1.

\section{DIAGRAM PENGGUNAAN E-LEARNING SEBAGAI MEDIA PEMBELAJARAN}

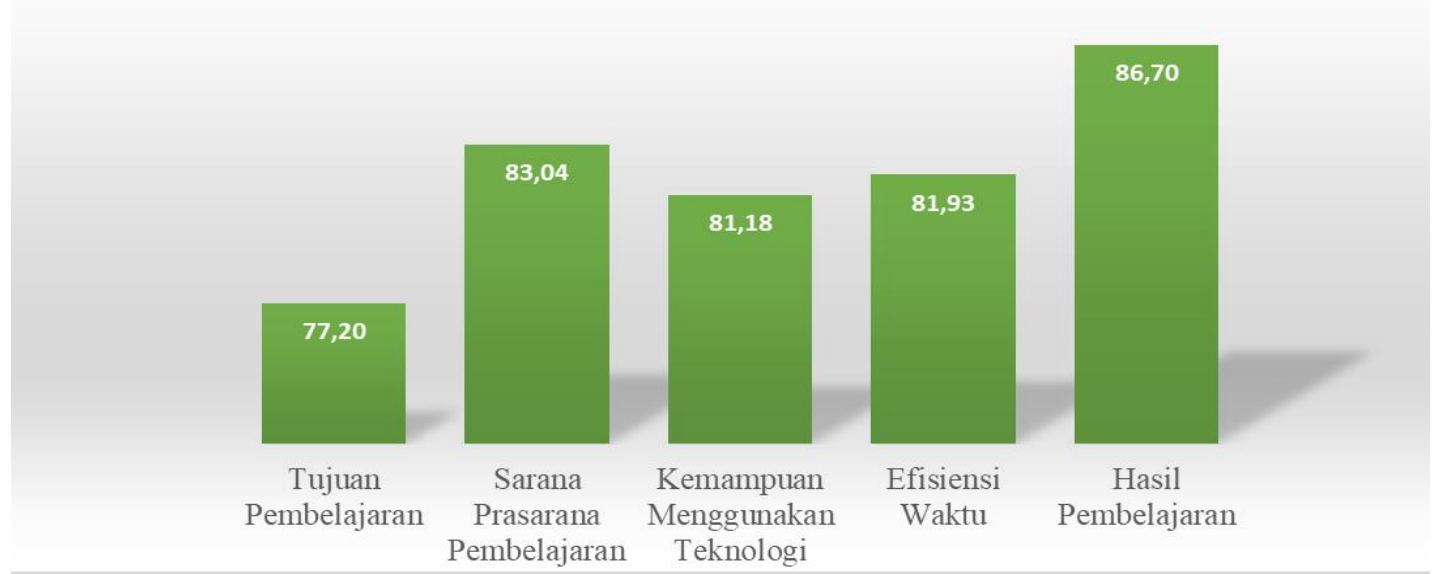

Gambar 1. Tingkat Capaian Responden (TCR) penggunaan E-learning sebagai media pembelajaran saat pandemi covid-19

\section{Pembahasan}

Penggunaan E-learning sebagai media pembelajaran saat pandemi covid-19 dikategorikan efektif. E-learning adalah salah satu proses dan kegiatan pembelajaran berbasis web dan komputer (Andel et al., 2020; Kim \& Sihyun Park, 2021). Materi dalam pembelajaran elektronik ini melalui media internet, audio, atau tape video melalui satelit televisi interaktif serta CD ROM (Alshammari, 2020; Nurliawaty et al., 2017). Konsep E-learning tidaklah baru dalam Pendidikan. E-learning merupakan bentuk pembelajaran yang memanfaatkan fasilitas teknologi yang membuat siswa juga akan belajar digital (Ogbonna et al., 2019; Sorensen, 2013). Pemanfaatan E-learning sebagai sumber belajar dan alat bantu dalam proses pembelajaran. Dalam proses pembelajaran, mahasiswa sebagai subjek harus berperan aktif dalam pembelajaran (Arifuddin et al., 2020; Permatasari \& Hardiyan, 2018; Wahyuni et al., 2020). Dalam mencapai pembelajaran itu maka system pada E-learning harus disajikan semenarik mungkin dan memudahkan mahasiswa dalam belajar.

Selain itu, E-learning dikatakan efektif sebagai proses kegiatan pembelajaran karena memiliki sifat fleksibel. Ciri dari E-learning yaitu tidak bergantung pada ruang dan waktu (Aini et al., 2020; Almaiah et al., 2020; Suprapto, 2019). Hal ini yang menyebabkan kegiatan pembelajaran dapat dilakukan kapanpun serta dimanapun siswa belajar (Logan et al., 2021; Luckyardi \& Rahman, 2021). Dengan teknologi ini, E-learning juga mampu menyediakan bahan ajar ataupun penyimpanan instruksi pembelajaran yang fleksibel (Madleňák, 2015; Nuryadi et al., 2020). Dengan demikian adanya E-learning ini akan memperpendek jarak dosen dan mahasiswa dalam belajar. Berdasarkan hal tersebut efektifnya sebagai proses kegiatan pembelajaran karena karena menyebabkan kenyamanan belajar pada mahasiswa. Temuan penelitian sebelumnya juga menyatakan bahwa E-learning membuat pembelajaran menjadi 
nyaman karena siswa dalam belajar kapanpun sesuai dengan keinginan (Barakhsanova et al., 2020; Zalat et al., 2021). Temuan penelitian lainnya juga menyatakan bahwa E-learning dapat meningkatkan hasil belajar siswa (Pratiwi et al., 2016; Virgiawan et al., 2018; Wahyuni et al., 2020). Dapat disimpulkan bahwa E-learning dapat membantu mahasiswa dalam belajar dan meningkatkan semangat serta motivasi belajar mahasiswa. Selain itu, E-learning juga dapat meningkatkan hasil belajar mahasiswa secara signifikan.

\section{SIMPULAN}

Berdasarkan hasil penelitian efektivitas penggunaan E-learning sebagai media pembelajaran saat pandemi covid-19 program studi pendidikan teknologi dan kejuruan Universitas Negeri Padang, dapat disimpulkan bahwa penggunaan E-learning sebagai media pembelajaran saat pandemi covid-19 dikategorikan efektif. Kategori cukup dan baik akan menjadi pedoman untuk ke depannya agar lebih efektifnya penggunaan E-learning sebagai media pembelajaran saat pandemi covid-19 dan bisa mencapai kategori sangat baik.

\section{DAFTAR PUSTAKA}

Abuhassna, H., Al-rahmi, W. M., Yahya, N., Aman, M., \& Megat, Z. (2020). Development of a new model on utilizing online learning platforms to improve students ' academic achievements and satisfaction. International Journal of Educational Technology in Higher Education, 17(73), 2-23. https://doi.org/10.1186/s41239-020-00216-z.

Abuhassna, H., Al-Rahmi, W. M., Yahya, N., Zakaria, M. A. Z. M., Kosnin, A. B. M., \& Darwish, M. (2020). Development of a new model on utilizing online learning platforms to improve students' academic achievements and satisfaction. International Journal of Educational Technology in Higher Education, 17(1), 1-23. https://doi.org/10.1186/S41239-020-00216-Z.

Aini, Q., Putra, P. O. H., Budiarto, M., \& Rahardja, U. (2020). Exploring E-learning Challenges During the Global COVID-19 Pandemic: A Review. Jurnal Sistem Informasi (Journal of Information System), 16(2), 57-65. https://doi.org/10.21609/jsi.v16i2.1011.

Ali, W. (2020). Online and Remote Learning in Higher Education Institutes: A Necessity in light of COVID19 Pandemic. Higher Education Studies, 10(3), 16-25. https://doi.org/10.5539/hes.v10n3p16.

Almaiah, M. A., Al-Khasawneh, A., \& Althunibat, A. (2020). Exploring the critical challenges and factors influencing the E-learning system usage during COVID-19 pandemic. Education and Information Technologies, 25(6), 5261-5280. https://doi.org/10.1007/s10639-020-10219-y.

Alshammari, M. T. (2020). Evaluation of gamification in e-learning systems for elementary school students. TEM Journal, 9(2). https: //doi.org/10.18421/TEM92-51.

Andel, S. A., de Vreede, T., Spector, P. E., Padmanabhan, B., Singh, V. K., \& Vreede, G. J. de. (2020). Do social features help in video-centric online learning platforms? A social presence perspective. Computers in Human Behavior, 113(April), 106505. https://doi.org/10.1016/j.chb.2020.106505.

Anitha Kumari, T., Hemalatha, C. H., Subhani Ali, M., \& Naresh, R. (2020). Survey on impact and learning's of the online courses on the present era. Procedia Computer Science, 172, 82-91. https://doi.org/10.1016/j.procs.2020.05.167.

Arifuddin, Suwatra, \& Mahadewi. (2020). Pengembangan Konten E-learning Berorientasi Pendidikan Karakter Pada Mata Pelajaran Seni Budaya. Jurnal Edutech Undiksha, 8(2). https://doi.org/10.23887/jeu.v8i2.28942.

Aris, B., Ardian, A., \& Ferry, M. (2019). Pengembangan Media Pembelajaran Berbasis E-Learning Pada SMK di Pontianak. Jurnal Nasional Komputasi Dan Teknologi Informasi (JNKTI), 2(2), 133. https://doi.org/10.32672/jnkti.v2i2.1556.

Astalini, A., Darmaji, D., Kurniawan, W., Anwar, K., \& Kurniawan, D. A. (2019). Effectivenes of Using EModule and E-Assessment. International Journal of Interactive Mobile Technologies (IJIM), 13(09), 21-39. https://doi.org/10.3991/ijim.v13i09.11016.

Barakhsanova, E. A., Prokopyev, M. S., Olesova, S. G., Olesov, N. P., Lukina, T. N., Sorochinskiy, M. A., \& Tatarinov, F. F. (2020). Transdisciplinary Approach To the Learning Process Organization in the E-Learning Information Environment of a College. International Transaction Journal of Engineering Management I\& Applied Sciences I\& Technologies, 11(3), 1-12. https://doi.org/10.14456/ITJEMAST.2020.53.

Bipinchandra, J. S. a/p, Shah, P. M., Puteh, S. N., Din, R., Rahamat, R., \& Aziz, J. A. (2014). User Needs Analysis in Learning Argumentative Writing Via Mobile Platform. Procedia - Social and Behavioral Sciences, 118. https://doi.org/10.1016/j.sbspro.2014.02.027.

Browning, M. H. E. M., Larson, L. R., Sharaievska, I., Rigolon, A., McAnirlin, O., Mullenbach, L., Cloutier, S., 
Vu, T. M., Thomsen, J., Reigner, N., Metcalf, E. C., D’Antonio, A., Helbich, M., Bratman, G. N., \& Alvarez, H. O. (2021). Psychological impacts from COVID-19 among university students: Risk factors across seven states in the United States. PloS One, 16(1), e0245327. https://doi.org/10.1371/journal.pone.0245327.

Calvo, C., López-hortelano, M. G., Carlos, J., Vicente, D. C., Luis, J., Martínez, V., ..., \& Asociación, D. (2020). Recommendations on the Clinical Management of the COVID-19 Infection by the (new Coronavirus) SARS-CoV2. Clinical Management of Infection, 92(4). https: //doi.org/10.1016/j.anpede.2020.02.002.

Gerhardt-Szép, S., Dreher, S., Rüttermann, S., \& Weberschock, T. (2017). Konzeption und Implementierung eines neuartigen E-Learning-Moduls mit EbM-Lerninhalten im Fach Zahnerhaltungskunde. Zeitschrift Für Evidenz, Fortbildung Und Qualität Im Gesundheitswesen, 127-128, 72-78. https://doi.org/10.1016/j.zefq.2017.09.001.

Guan, W., Ni, Z., Hu, Y., Liang, W., Ou, C., He, J., Liu, L., Shan, H., Lei, C., Hui, D. S. C., Du, B., Li, L., Zeng, G., Yuen, K.-Y., Chen, R., Tang, C., Wang, T., Chen, P., Xiang, J., ... Zhong, N. (2020). Clinical Characteristics of Coronavirus Disease 2019 in China. New England Journal of Medicine, 382(18), 1708-1720. https://doi.org/10.1056/NEJMoa2002032.

Hanik, E. U. (2020). Self directed learning berbasis literasi digital pada masa pandemi covid-19 di Madrasah Ibtidaiyah. ELEMENTARY: Islamic Teacher Journal, 8(1), 183. https://doi.org/10.21043/elementary.v8i1.7417.

Hincal, E., \& Alsaadi, S. H. (2021). Stability analysis of fractional order model on corona transmission dynamics. Chaos, Solitons \& Fractals, 143, 110628. https://doi.org/10.1016/j.chaos.2020.110628.

Iswara, I. B. A. I., \& Yasa, I. P. P. K. (2021). Analisis Dan Perbandingan Quality Of Service Video Conference Jitsi Dan Bigbluebutton Pada Virtual Private Server. Jurnal Resistor, 4(2). https://doi.org/10.31598/jurnalresistor.v4i2.794.

Khamparia, A., \& Pandey, B. (2017). Impact of interactive multimedia in E-learning technologies: Role of multimedia in E-learning. Enhancing Academic Research With Knowledge Management Principles, April, 199-227. https://doi.org/10.4018/978-1-5225-2489-2.ch007.

Khasawneh, R., Simonsen, K., Snowden, J., Higgins, J., Beck, G., Khasawneh, R., Simonsen, K., Snowden, J., Higgins, J., \& Beck, G. (2016). The Effectiveness of E-Learning in Pediatric Medical Student Education. Medical Education Online, 21(1), 1-3. https://doi.org/10.3402/meo.v21.29516.

Kim, S.-H., \& Sihyun Park. (2021). Influence of Learning Flow and Distance E-Learning Satisfaction on Learning Outcomes and the Moderated Mediation Effect of Social-Evaluative Anxiety in Nursing College Students during the COVID-19 Pandemic: A Cross-Sectional Study. Nurse Education in Practice, 6(103197). https://doi.org/10.1016/j.nepr.2021.103197.

Logan, R. M., Johnson, C. E., \& Worsham, J. W. (2021). Development of an E-learning Module to Facilitate Student Learning and Outcomes. Teaching and Learning in Nursing, 16(2), 139-142. https://doi.org/10.1016/j.teln.2020.10.007.

Luckyardi, S., \& Rahman, L. (2021). Application of E-Learning System in the World of Education. Jurnal Teknologi Informasi Dan Pendidikan, 14(1), 47-52. https://doi.org/10.24036/tip.v14i1.327.

Madleňák, R. et al. (2015). Designing a Social Network to Support E-learning Activities at the Department of Communications, University of Žilina. Procedia - Social and Behavioral Sciences, 176, 103-110. https://doi.org/10.1016/j.sbspro.2015.01.449.

Maulana, H. A. \&, \& Iswari, R. D. (2020). Analisis Tingkat Stres Mahasiswa Terhadap Pembelajaran Daring Pada Mata Kuliah Statistik Bisnis di Pendidikan Vokasi. Jurnal Ilmiah Kependidikan, 14(1), 17-30. https://doi.org/10.30595/jkp.v14i1.8479.

Mayer, R. E. (2017). Using multimedia for e-learning. Journal of Computer Assisted Learning, 33(5), 403423. https://doi.org/10.1111/jcal.12197.

Nurliawaty, L., Mujasam, M., Yusuf, I., \& Widyaningsih, S. W. (2017). Lembar Kerja Peserta Didik (LKPD) Berbasis Problem Solving Polya. JPI (Jurnal Pendidikan Indonesia), 6(1), 72-81. https://doi.org/10.23887/jpi-undiksha.v6i1.9183.

Nuryadi, N., Kurniawan, L., \& Kholifa, I. (2020). Developing mobile learning based on ethnomathematics viewed from adaptive e-learning: Study of two dimensions geometry on Yogyakarta palace's chariot. International Journal of Education and Learning, 2(1), 32-41. https://doi.org/10.31763/ijele.v2i1.85.

Ogbonna, C. G., Ibezim, N. E., \& Obi, C. A. (2019). Synchronous versus asynchronous e-learning in teaching word processing: An experimental approach. South African Journal of Education, 39(2), 1-15. https://doi.org/10.15700/saje.v39n2a1383.

Permatasari, I., \& Hardiyan, H. (2018). Pengaruh E-Learning Sebagai Media Pelatihan dan Pengembangan Terhadap Kinerja Karyawan BCA KCU Tangerang. Jurnal Sisfokom (Sistem Informasi Dan 
Komputer), 7(1), 1. https://doi.org/10.32736/sisfokom.v7i1.275.

Pratiwi, I., Suartama, I. K., \& Tegeh, I. M. (2016). Pengembangan E-Learning dengan Model Prototype Berorientasi Model Pembelajaran Inquiry Siswa Kelas VII SMPN 2 Negara. Jurnal Edutech Undiksha, 4(2). https://doi.org/10.23887/jeu.v4i2.7615.

Putri, V. D. (2020). Layanan Bimbingan dan Konseling Daring Selama Masa Pandemi COVID-19. Jurnal Bimbingan Konseling Pendidikan Islam, 1(2), 7-16. https://doi.org/10.47453/coution.v1i2.95.

Rangga, P., Wirasti, M. K., \& Kustandi, C. (2016). Bahan Belajar Mandiri Pengoperasian BigBlueButton Bagi Mentor/Pengampu Program Guru Pembelajar. Jurnal Pembelajaran Inovatif, 1(1). https://doi.org/10.21009/JPI.011.02.

Sayıner, A. A., \& Ergönül, E. (2021). E-learning in clinical microbiology and infectious diseases. Clinical Microbiology and Infection, 28. https://doi.org/10.1016/j.cmi.2021.05.010.

Shah, K., Arfan, M., Mahariq, I., Ahmadian, A., Salahshour, S., \& Ferrara, M. (2020). Fractal-Fractional Mathematical Model Addressing the Situation of Corona Virus in Pakistan. Results in Physics, 19, 103560. https://doi.org/10.1016/j.rinp.2020.103560.

Shetu, S. F., Rahman, M. M., Ahmed, A., Mahin, M. F., Akib, M. A. U., \& Saifuzzaman, M. (2021). Impactful elearning framework: A new hybrid form of education. Current Research in Behavioral Sciences, 2(April), 100038. https://doi.org/10.1016/j.crbeha.2021.100038.

Soni, Hafid, Hayami, Fatma, Wenando, Amien, Fuad, Unik, \& Mukhtar. (2018). Optimalisasi Penggunaan Google Classroom, E-Learning \& Blended Learning sebagai Media Pembelajaran Bagi Guru dan Siswa di SMK Negeri 1 Bangkinang. Jurnal Pengabdian Untukmu Negeri, 21. https://doi.org/10.37859/jpumri.v2i1.361.

Sorensen, E. (2013). Implementation and student perceptions of e-assessment in a Chemical Engineering module. European Journal of Engineering Education, 38(2), 172-185. https://doi.org/10.1080/03043797.2012.760533.

Sugiyono. (2018). Metode Penelitian Pendidikan Pendekatan Kuantitatif, Kualitatif dan R\&D. Alfa Beta.

Suprapto, A. (2019). Analisis dimensi kebutuhan pra implementasi e-learning untuk meningkatkan mutu layanan pendidikan kampus di era revolusi industri 4.0. Attarbiyah, 28, 81. https://doi.org/10.18326/tarbiyah.v28i0.81-97.

Tamboto, H., Tambingon, H. N., Lengkong, J. S. ., \& Rotty, V. N. J. (2021). The Involvement of Students' Parents in Organizing the Learning from Home at Elementary Schools in Tomohon City. Asia Pacific Journal of Management and Education, 4(1), 35-51. https://doi.org/10.32535/apjme.v4i1.1044.

Tang, Y. M., Chen, P. C., Law, K. M. Y., Wu, C. H., Lau, Y., Guan, J., He, D., \& Ho, G. T. S. (2021). Comparative analysis of Student's live online learning readiness during the coronavirus (COVID-19) pandemic in the higher education sector. Computers \& Education, 168, 104211. https://doi.org/10.1016/j.compedu.2021.104211.

Velan, G. M., Goergen, S. K., Grimm, J., \& Shulruf, B. (2015). Impact of Interactive e-Learning Modules on Appropriateness of Imaging Referrals: A Multicenter, Randomized, Crossover Study. Journal of the American College of Radiology, 12(11). https://doi.org/10.1016/j.jacr.2015.06.026.

Virgiawan, M. D., Meryansumayeka, \& Marlini, S. (2018). Pengembangan Kuis Interaktif Berbasis ELearning Dengan Menggunakan Aplikasi Wondershare Quiz Creator Pada Mata Kuliah Belajar Dan Pembelajaran Matematika. Jurnal Pendidikan Matematika, 12(1), 29-42. https://doi.org/10.22342/jpm.12.1.5094.29-42.

Wahyuni, A. S., Warpala, I. W. S., \& Agustini, K. (2020). Pengembangan Konten E-Learning Berbasis Self Regulated Learning untuk Meningkatkan Hasil Belajar Airline Reservation. Jurnal Teknologi. https://doi.org/10.23887/jtpi.v10i1.3394.

Weldon, A., Ma, W. W. K., Ho, I. M. K., \& Ma, W. W. K. (2021). Online learning during a global pandemic: Perceived benefits and issues in higher education. Knowledge Management \& E-Learning, 13(2), 161-181. https://doi.org/10.34105/j.kmel.2021.13.009.

Wen, J., Cheng, Y., Ling, R., Dai, Y., Huang, B., Huang, W., Zhang, S., \& Jiang, Y. (2020). International Journal of Infectious Diseases Antibody-dependent enhancement of coronavirus. International Journal of Infectious Diseases, 100, 483-489. https://doi.org/10.1016/j.ijid.2020.09.015.

Yulia, H. (2020). Online Learning to Prevent the Spread of Pandemic Corona Virus in Indonesia. English Teaching Journal, 11, 48-56. https://doi.org/10.26877/eternal.v11i1.6068.

Zalat, M. M., Hamed, M. S., \& Bolbol, S. A. (2021). The experiences, challenges, and acceptance of elearning as a tool for teaching during the COVID-19 pandemic among university medical staff. PLoS ONE, 16(3), 1-12. https://doi.org/10.1371/journal.pone.0248758. 